\title{
What Do Not-For-Profit Corporations Need To Do, In Order To Maintain Their Tax-Exempt Status?
}

\section{Seyam $A^{1 *}$ and Kotkin $E^{2}$}

${ }^{1}$ Borough of Manhattan Community College, USA

${ }^{2}$ Financial Services, Ernst and Young

\begin{abstract}
This paper will discuss the process that not-for-profit (NFP) organizations must undergo to qualify for tax-exempt status. It will begin by discussing the steps that must be followed in order for not-for-profit organizations to receive tax-exempt status, as well as what they must do in order to maintain that status. It will then explain the rules these organizations must follow to remain exempt, the activities that can jeopardize their tax exempt status, and the effect of losing said status with specific focus on the rules dictating automatic revocation of tax exempt status. The article will then conclude with some recommendations that can be implemented to improve the effectiveness of charitable organizations.
\end{abstract}

Keywords: Not-for-profit; NFP; Tax-exempt; Automatic revocation; Reinstatement

\section{Introduction}

Holding the status of a NFP organization does not mean that the organization has no intention of making a profit. Rather, it means that the organization has no owners and any profits earned will not be used to benefit any private interest. Private NFP organizations are a significant component of the U.S. economy. NFP organizations receive contributions from donors that do not expect a return of equivalent financial benefit. Unlike for-profit companies, NFPs don't have any owner's interest in mind and their operating purpose is not to provide goods and services for a profit. NFP organizations can be maintained either by the government or private parties [1-5]. Examples of NFPs are: charities, trade organizations, political parties, civic organizations, health organizations, religious organizations, and educational organizations. As long as NFP organizations follow guidelines set by the Financial Accounting Standards Board (FASB) or Government Accounting Standards Board (GASB) (for private and governmental NFPs respectively), and file the correct tax forms, they can be eligible for tax-exempt status. This means they are exempt from federal taxation and often state taxation as well. Donors also receive a deduction to their own taxable income for any contributions made. Once a NFP organization has received tax-exempt status, they must continue to follow the guidelines and file special tax forms each year in order to maintain their tax-exempt status.

\section{How not-for-profit entities qualify for tax-exempt status}

There are a number of sections of the Internal Revenue Code that allow NFP organizations to be exempt from paying federal income taxes, the most important of which are Sections 501(c)(3), 501(c)(4), and 501(c)(6). Section 501(c)(3) applies to charitable, educational, or scientific organizations, and covers the majority of NFP tax-exempt entities [6-10]. Section 501(c)(4) applies specifies to advocacy groups. Section 501(c)(6) applies to business leagues and boards of trade.

To receive tax-exempt status under section 501(c)(3) of the Internal Revenue Code, an organization must meet the following requirements:

It must be organized and operated exclusively for exempt purposes enumerated in 501(c)(3) individual
It may not attempt to influence legislation as a substantial part of its activities, and

\section{It may not participate in any political activity}

The most common types of 501(c)(3) organizations are:

- charitable,

- educational, and

- religious

Some organizations that qualify for tax exemption under section 501(c)(3) must file IRS Form 1023. According to the IRS website, in order to seek tax-exempt status, a NFP organization must complete the IRS Form 1023 (Application for Recognition of Exemption Under Section 501(c)(3) of the Internal Revenue Code). It is important to apply for tax-exempt status within the first 27 months of a NFP organization's inception, as doing so means that the organization's tax exempt status will have been effective as of the date of the organization's being formed $[11,12]$. However, if a NFP organization files after the first 27 months of its inception, the company must show reasonable cause for its delay or its tax-exempt status will take effect on the date of the form's completion. Form 1023 is comprised of 11 sections. Churches and religious organizations that are not private foundations and have less than $\$ 5,000$ in gross receipts are examples of organizations that do NOT need to file Form 1023.

The next section is 501(c)(4) and generally applies to organizations such as civic leagues or other corporations operated solely for the promotion of social welfare, which is "primarily engaged in promoting in some way the common good and general welfare of the people of

*Corresponding author: Seyam A, Borough of Manhattan Community College, USA, Tel: +1 212-220-8000; E-mail: aseyam@bmcc.cuny.edu

Received January 14, 2016; Accepted March 25, 2016; Published March 30 2016

Citation: Seyam A, Kotkin E (2016) What Do Not-For-Profit Corporations Need To Do, In Order To Maintain Their Tax-Exempt Status? Int J Account Res 4: 122 doi:10.4172/2472-114X.1000122

Copyright: ( 2016 Seyam A, et al. This is an open-access article distributed under the terms of the Creative Commons Attribution License, which permits unrestricted use, distribution, and reproduction in any medium, provided the original author and source are credited. 
the community, i.e. primarily for the purpose of bringing about civic betterments and social improvements" (IRS, 1981). These organizations must devote net earnings exclusively to charitable, recreational, or educational purposes. Unlike organizations under section 501(c)(3), 501(c)(4) organizations are allowed to attempt to influence legislation that is relevant to their agenda. They are also allowed to take part in political campaigns so long as their goal is to promote social welfare. Although a majority of 501(c)(4) organizations' operations are included under the tax exemption, donors may still be subject to gift taxes on their donations and income spent on political activities is usually taxable to the 501(c)(4).

Section 501(c)(6) organizations generally include business leagues. Business leagues are defined as associations of persons promoting some common business interest but not actually engaging in that business for profit [13-16]. This includes companies such as the U.S Chamber of Commerce and the National Football League.

\section{How not-for-profit corporations maintain their tax-exempt status}

In order to maintain their tax exempt status, the IRS also requires these organizations to maintain certain levels of reporting and public disclosure. An organization that fails to follow these rules and regulations may end up losing its tax-exempt status. These regulations include:

Private benefit - IRS regulations prohibit a private shareholder or individual, an insider of exempt organizations to be permitted by the organization to benefit substantially from its activities. An insider is someone who has an interest in the activities of the organization [17]. The law defines a "private shareholder or individual" as any person having a personal and private interest in the activities of the organization. This includes officers, directors, or key employees of the NFP. Unreasonable or excessive compensation is one of the most common ways insiders in these organizations receive private benefits.

Case: Anclote Psychiatric Center Inc v Commissioner US Tax Court (Jul. 27, 1998).

In this case, a non-profit organization sold a hospital for less than fair market value. The purpose behind this below fair market value sale was to benefit the private individual shareholders of the purchasing organization. The Tax Court evaluated the business appraisal of the hospital. It made certain adjustments to the value of the hospital and based on the revised figures, it concluded that the sale price was outside the reasonable limits of the fair market value. The IRS revoked the tax exempt status of the non-profit organization on the ground that it worked for the private benefits of individuals.

Lobbying - The IRS permits 501(c)(3) organizations to engage in some level of lobbying so long as the lobbying activities do not to constitute a substantial portion of the organization's activities. Lobbying means attempting to influence legislation. However, a nonprofit entity is permitted to involve itself in issues of public policy by conducting educational meetings, and preparing and distributing educational materials. There are two tests that are used to measure the extent to which an entity is involved in lobbying activities:

Substantial Part Test - This test takes into consideration the amount of time spent on lobbying activities and the expenditures devoted by the organization to lobbying activity $[18,19]$.

Expenditure Limitation Test - By filing Form 5768, non-profit organizations (other than churches and private foundations) may elect that their lobbying activities be measured by the expenditure test under section 501(h). Section 4911(c)(2) specifies the limits within which an entity can spend on lobbying activities without jeopardizing its tax exempt status (Table 1).

Political campaign activity - Section 501(c)(3) organizations and their representatives (in their official capacity) are prohibited from engaging in any political campaign activities for or against candidates for elected office.

Case: Branch Ministries and Dan Little, Pastor, Appellants v. Charles O. Rossotti, Commissioner, Internal Revenue Service, Appellee, U.S. Court of Appeals, District of Columbia Circuit (May 12, 2000).

In this case, the tax exempt status of a church was revoked on the ground that it sponsored a newspaper advertisement urging people not to vote for a presidential candidate. In 1992, a couple of days before the presidential election, Branch Ministries placed advertisements in newspapers urging Christians not to vote for the presidential candidate Bill Clinton. The IRS concluded that this was a political campaign activity as it violated the statutory restrictions on tax exempt organizations under Section 501(c)(3). For the first time in its history, IRS revoked the tax exempt status of a church because of its engaging in political campaign activity.

Unrelated business income (UBI) - Section 501(c)(3) organizations are expected to carry out only those activities which relate to the exempt purpose for which they were formed. If the organization generates too much income from activities that are unrelated to its exempt purpose, it may lose its tax exempt status and also may have to pay taxes on that income [20-24].

Case: US District Court Dist Md Mrs Philippines Home for Senior Citizens Inc.

Mrs. Philippines' Home for Senior Citizens, Inc. was an organization deemed exempt from federal income taxes under Section 501(c)(3). As part of its fundraising activities, it received permission to run casino nights so long as the casinos were operated by unpaid volunteers and the proceeds went to charity. However, after some time, these casino nights were not restricted to mere bingo sessions. Rather, they turned into Las Vegas-type casino operations that started at noon and lasted until midnight, involving hundreds of workers. The Internal Revenue Service revoked Mrs. Philippines' tax-exempt status on the basis that she had the liability for unrelated business income tax.

Not operating in accordance with the stated exempt purpose An organization under Section 501(c)(3) has to file an application for recognition of tax-exempt status (Form 1023). In this application, the organization must detail the charitable purpose or purposes for which

\begin{tabular}{|c|c|}
\hline If the exempt purposes expenditures are: & The lobbying nontaxable amount is: \\
\hline Not over $\$ 500,000$ & 20 percent of the exempt purpose expenditures \\
\hline Over $\$ 500,000$ but not over $\$ 1,000,000$ & $\$ 100,000$, plus 15 percent of the excess of the exempt expenditures over $\$ 500,000$ \\
\hline Over $\$ 1,000,000$ but not over $\$ 1,500,000$ & $\$ 175,000$ plus 10 percent of the excess of the exempt purpose expenditures over $\$ 1,000,000$ \\
\hline Over $\$ 1,500,000$ & $\$ 225,000$ plus 5 percent of the excess of the exempt purpose expenditures over $\$ 1,500,000$ \\
\hline
\end{tabular}

Table 1: Expenditures and lobbying nontaxable amount. 
it is formed. The organization is expected to operate in accordance with this stated exempt purpose(s). In the event it makes any substantial changes to its operating purpose, it must notify the IRS.

Annual reporting obligation - All 501(c)(3) charitable organizations (except churches and religious organizations as stated aboved) are required to file annually some version of the Form 990 with the IRS. Earlier, smaller organizations with gross receipts under $\$ 25,000$ used to be exempt this annual reporting requirement. Currently, under the new rules these charities must now file the Form 990-N (Electronic Notice or e-Postcard) every year to retain their tax exempt status.

There is a final requirement that when a not-for-profit corporation dissolves, all of its assets must be distributed to other tax-exempt groups. Since all of the assets possessed by a not-for-profit are never technically "owned", they can never be sold. Instead, they must be donated to another NFP corporation. The reason they must be donated to a not-for-profit rather than a for-profit corporation is in order to ensure these assets cannot be distributed to shareholders or owners at a later date.

NFP organizations must take steps to actively maintain their tax exempt status. In order to fulfill their requirements, they must uphold an effective organizational structure. They must have a board of directors who make the important decisions for the NFP. They also must keep accurate FASB (or GASB) compliant records. These records must be sufficiently detailed to guard its directors from indemnity and protect the tax exempt status of the organization. Minutes of directors meetings and important corporate decisions must be documented. A corporate records book must be maintained, which should include a copy of the articles of incorporation, bylaws, and tax exemption letters from IRS. The NFP corporations must record their financial transactions in a bookkeeping system and keep other official financial records in order to file an annual corporate tax return.

\section{Advantages of receiving the NFP status from the government}

Exemption from Federal Income Tax - Generally an exempt organization enjoys exemption from Federal income tax. According to Bolder Advocacy's “The Benefits of Obtaining 501(c)(3) Tax Exemption," an organization can save between 15 and 35 percent of its taxable income by attaining tax-exempt status (2012).

Eligibility to receive tax-deductible charitable gifts under section 170 - Charitable contributions made to the exempt organizations may qualify for deduction on donors' Federal and state income tax returns. According to David Carnes' "Tax Benefits for Donating to a 501(c)(3)" (2015) for the most part, up to 50\% of one's adjusted gross income may be deducted as a result of donating to 501(c)(3) organizations. The following donations are subject to a $30 \%$ limitation: donations to veterans' organizations, fraternal societies, NFP cemeteries, and certain charities that provide funds to other organizations rather than the general public. Gifts of property for the actual use of the organization rather than for raising cash or distribution to the public are similarly capped at $30 \%$ as is capital gain property such as corporate stock that would otherwise qualify for the regular $50 \%$ deduction. Capital gain property donated for use of the organization itself is capped at 20\%. Funding Change (Carnes, ibid.), a training-and-consulting organization, reports that $75 \%$ of charitable contributions are from individuals. As an additional incentive to donate to NFP organizations, the IRS allows for excess contributions to be carried over for up to a maximum of five years of future tax deduction benefit. Businesses may deduct up to $10 \%$ for charitable contributions and excess contributions may be carried forward for five years and are deductible only if the current-year contributions are less than the current year's $10 \%$ limitation.

Possible exemptions from some state and local taxes - Section 501(c)(3) organizations may be exempt from state taxes like state income tax, state franchise tax, sales tax, or property tax. As the 501c3GO website states (2015), NFP organizations with 501(c)(3) tax-exempt status are automatically exempt from paying state taxes in the following states: Alaska, Colorado, Connecticut, Hawaii, Idaho, Illinois, Kansas, Louisiana, Michigan, Mississippi, Missouri, Nebraska, New Mexico, North Dakota, Oklahoma, Oregon, South Carolina, Virginia, West Virginia, Wisconsin. In addition, many other states, including New York, make state tax exemption fairly easy to attain, by simply notifying the NFP organization's state of having secured 501(c) (3) tax-exempt status.

Bulk postal rate privileges - Section 501(c)(3) organizations qualify for a NFP rate and for a bulk mail rate. Board member protection from personal liabilities: An additional benefit of having tax-exempt status is that the NFP organization's board members and other personnel are protected from personal liabilities for unpaid debts or lawsuits imposed upon the organization.

Public Trustworthiness: A NFP organization that is classified as 501(c)(3) usually appears as credible and trustworthy in the eyes of the public.

\section{Automatic Revocation}

The IRS is required to publish and maintain a list of the organizations that have lost their tax-exempt status due to automatic revocation. The IRS published its first list on June 8, 2011. The IRS website now includes the Automatic Revocation of Exemption List, which organizations are encouraged access the database frequently to check on their status.

\section{Current situation}

According to a Global Newswire article, the top 100 NFPs who had their tax-exempt status revoked by the IRS brought in revenues of \$4$\$ 400$ million annually. In December 2010, the IRS identified 321,091 NFPs at risk of losing their exemptions for failure to file (Figure 1).

The vast majority of these organizations-82 percent-were not required to file an annual return before the Pension Protection Act was passed, which indicates that their annual incomes were $\$ 25,000$ or

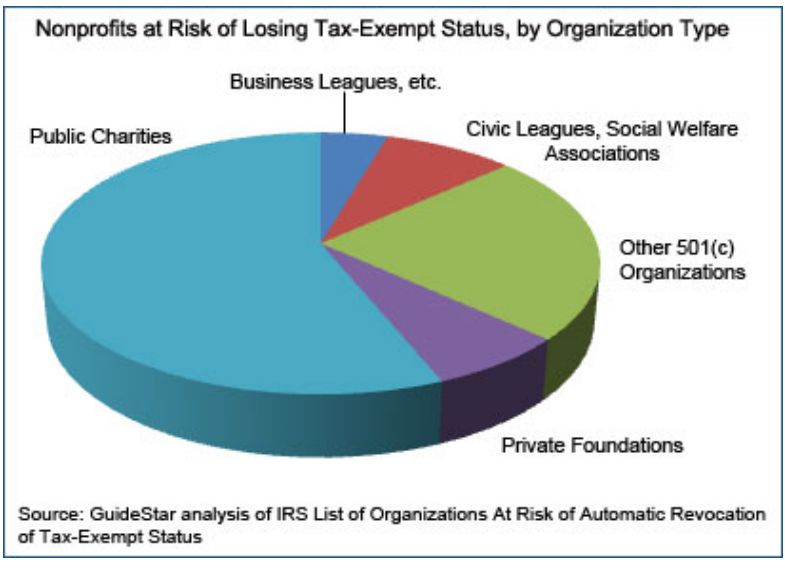

Figure 1: NFPs at risk of losing their exemptions. 
less. In 2011, according to Christopher Bird's "275,000 NFPs Lose TaxExempt Status," the IRS announced that approximately 275,000 NFP organizations had lost their respective tax-exempt status for this very reason. More than half (57 percent) of the revoked organizations were 501(c)(3) public charities. According to the aforementioned Global Newswire article, the revocation of these 275,000 NFP organizations as tax-exempt entities brought the NFP tax-exempt sector down by 17 percent.

\section{Reinstatement}

The penalty of automatic revocation can be dismissed through the process of reinstatement. NFPs always desire to maintain their tax-exempt status because of the numerous benefits that accompany tax exempt status. However, an organization's status may get revoked automatically due to non-material reasons and the following process can help the organization to have its status reinstated.

The first step is for the organization to file an application for exemption (Form 1023 or Form 1024) and pay the appropriate user fee, ranging from $\$ 400$ to $\$ 850$, even if the organization was not required to apply for exempt status when it first organized. The IRS will look into the application and if the organization has showed reasonable cause for its consecutive filing failures, the organization's tax-exempt status may, at the discretion of the Secretary, be reinstated. Then IRS will issue a new determination letter, announcing the tax-exempt status of the organization. Subsequently, the reinstated organization will be included in the next update of Exempt Organizations Select Check (Pub. 78 database), and it will be indicated in the IRS Business Master File (BMF) extract that the organization is eligible to receive taxdeductible contributions. Donors, private foundations, and others will then rely on the new IRS determination letter as of its stated effective date and on the updated Exempt Organizations Select Check and BMF extract listings to select the targets to make donations.

Under most circumstances, the effective date of reinstated exemption is the date when the organization submits its exemption application to the IRS. The organization may also request that reinstatement be retroactive to the effective date of revocation when filling the reinstatement application. Since the organization has to pay federal income tax and any other applicable taxes for the time between the revocation and reinstatement of its exemption, such a request, if granted, will help the organization save a lot of money. The IRS grants retroactive reinstatement of exemption under certain limited circumstances.

Additionally, the IRS advises organizations writing "Automatically Revoked" at the top of the reinstatement application, as well as on the submitted envelope, so that the application will go to a the hand of a specialist who is trained to handle these applications. Ultimately, any applications will reach the hand of an experienced tax professional, such as a Certified Public Accountant (CPA). The expertise of the tax professional will help ensure accuracy of the reinstatement application and supporting documentation.

\section{Implications of losing tax exempt status}

The tax benefits brought by tax exempt status will disappear if the organization loses itstax exempt status. Therefore, when the eligible organizations conduct any of the aforementioned activities listed, the following repercussions will occur:

1. Pay federal taxes - Once the status is lost, the NFP organization is no long exempt from federal income tax. It may be required to file
Form 1120 (U.S. Corporation Income Tax Return) or Form 1041 (U.S. Estate and Trust Income Tax Return) of federal income tax returns and have to pay corporate income tax on annual revenue.

2. May be required to pay back taxes - The organization may also be charged backed taxes and penalties, because it has failed to pay the applicable amount of income taxes as of the effective date of revocation.

3. Revocation of state exemptions - All the exemptions received from the state including property tax, income tax, sales tax, etc. that are dependent on federal tax-exempt status may also be revoked.

4. Removal of name from official list of exempt organizations - Arguably of more importance, it will significantly diminish a NFP organization's ability to raise money. The organization will be removed from the list of exempt organizations that are eligible to receive tax deductible contributions from the donors. IRS monthly updates Exempt Organizations Select Check database (Pub. 78 Data), where all eligible organizations that receive tax-deductible charitable contributions are listed. An organization that has lost the exempt status will not be in the list, so donors will likely not consider donating to such an organization while there are thousands of other eligible organizations. This consideration applies not only to personal donors, but also private foundations as well. This means that the donors will not be eligible to receive tax deduction for donations or contributions made after revocation date. The IRS may disallow the deduction, and donors may be required to pay a penalty on the retroactively backed taxes. If an organization that is an eligible $403(\mathrm{~b})^{1}$ plan sponsor lost its tax-exempt status, it is no longer eligible to sponsor a 403(b) plan. Thus, the employer and employee contributions to the 403(b) plan must be stopped. If the contributions have not been discontinued, the organization may have to withhold payroll taxes from the contributions, and the plan participants may be liable for additional income taxes because the contributions are not tax-deferred. However, the organization can use the IRS Voluntary Correction Program (VCP) to correct its eligibility failure, if plan participants have allowed contributions to be made to the 403(b) plan after the organization lost its tax-exempt status.

\section{Protecting the tax-exempt status}

NFP organizations must do the following in order to protect their tax-exempt status and continue enjoying the privileges available to 501(c)(3) organizations:

1. Keep accurate financial records - Since a NFP do not have shareholders or owners, and the profits cannot be distributed, detailed and accurate financial record-keeping will demonstrate that no profits were distributed to directors and that all of the money has been accounted for. If the NFP entity is dissolved, its asset must go to another non-profit organization.

2. Comply with corporate formalities - The NFP organization must monitor its activities to make sure it is in line with its mission statement originally submitted to the IRS. The Board of Directors must elect people who will ensure NFP's annual reporting obligations are met.

3. File annual returns - A NFP must file annually Form 990 "Return of Organization Exempt From Income Tax", Form 990-EZ

1403(b) plan is a U.S. tax-advantaged retirement savings plan available for public education organizations, employers of Internal Revenue Code 501(c) (3) organizations, cooperative hospital service organizations, and selfemployed ministers 
Citation: Seyam A, Kotkin E (2016) What Do Not-For-Profit Corporations Need To Do, In Order To Maintain Their Tax-Exempt Status? Int J Account Res 4: 122. doi:10.4172/2472-114X.1000122

Page 5 of 5

"Short Form Return of Organization Exempt From Income Tax", or Form 990-N "Electronic Notice (e-Postcard) for Tax-Exempt Organizations Not Required To File Form 990 or 990-EZ". It is important to file the appropriate form within five and a half months from the end of the entity's fiscal year. Otherwise, the entity's taxexempt status may be revoked. This will occur after three years of delinquency of filing annual Form 990, 990-EZ or 990-N.

4. Pay any appropriate taxes - A NFP must pay taxes on any gross unrelated business income of $\$ 1,000$. If the NFP has employees, all appropriate FICA taxes must be paid. The success of a NFP and its tax-exempt status will depend on maintaining its good standing with IRS.

5. Refrain from engaging in activities that would jeopardize its tax exempt status - The organization must refrain from engaging in political campaigns and lobbying activities. It must not engage in activities for personal gain and must limit its business activities to those related to its stated purpose. If it is necessary to conduct such activities, the Board of Directors must establish a separate entity for these activities with an aid of an attorney.

\section{Conclusion}

There are many steps and guidelines not-for-profit organizations must follow in order to receive a tax-exempt status. Even once they have obtained this status, there are many rules, stated by the IRS, they must follow in order to avoid losing their tax-exempt status. Not only must they comply with these rules, but also they must make sure to file the correct tax forms, such as Form 990, along with their tax return each year. There are several different sections of the Internal Revenue Code that discuss the rules for the majority of not-for-profits, and their eligibility for tax-exempt status. Tax-exempt status means that the corporation is exempt from federal taxes, and in most cases states taxes as well. Donors can receive a reduction in their own taxable income, if they donate to a not-for-profit organization without receiving any economic benefit.

\section{References}

1. http://www.nolo.com/legal-encyclopedia/protecting-NFP-corporation-taxexempt-status-29895.html
2. http://www.irs.gov/Charities-\%26-Non-Profits/Charitable-Organizations/ Exemption-Requirements-Section-501(c)(3)-Organizations

3. http://www.cpa2biz.com/Content/media/PRODUCER_CONTENT/Newsletters/ Articles_2013/CorpTax/HelpNFPs.jsp

4. http://law.richmond.edu/people/PDF/HowToFormANFP_1st_ed-Chapter3.pdf

5. http://www.irs.gov/pub/irs-pdf/p4221pc.pdf

6. http://www.nolo.com/legal-encyclopedia/protecting-NFP-corporation-taxexempt-status-29895.html

7. http://www.councilofNFPs.org/resources/admin-management/jeopardizingtax-exempt-status

8. http://www.irs.gov/Charities-\&-Non-Profits

9. http://www.independentsector.org/uploads/Accountability_Documents/ Principles_Workbook.pdf

10. http://www.urban.org/UploadedPDF/311363_NFP_governance.pdf

11. http://www.independentsector.org/uploads/Accountability_Documents/ sarbanes_oxley_implications.pdf

12. http://www.neh.gov/files/divisions/fedstate/panel_final_report.pdf

13. http://www.pgdc.com/pgdc/irs-releases-compliance-guide-tax-exemptorganizations-other-501c3-public-charities-and-private-foundations

14. $h$ ttp://www.findlaw.com/?DCMP=GOO-FLAW_Brand-Name\&HBX_PK=findlaw

15. http://www.venable.com/the-difference-between-NFP-and-tax-exemptstatus-10-02-1999/

16. http://www.urban.org/publications/412736.html

17. http://bolderadvocacy.org/wpcontent/uploads/2012/05/The_Benefits_of_ Obtaining_501c3_Tax_Exemption.pdf

18. http://finance.zacks.com/tax-benefits-donating-501c3-2724.html

19. http://501c3go.com/

20. Steven F (2012) Every NFP's Tax Guide: How to keep your tax-exempt status and avoid IRS problems. Berkeley.

21. Alexander S, John S, William S (2012) Tax guide for tax exempt status.

22. Mark B (1992) Protecting your organization's tax-exempt status: A guide for nfp managers, San Francisco.

23. Bruce R. (2011) The law of tax exempt organizations (Wiley NFP Authority). John Wiley \& Sons Inc.

24. Dan $P$ (2012) Charity case: How the NFP community can stand up for itself and really change the world, San Francisco. 